\title{
CONTEMPORARY TERRORISM IN THE EUROPEAN UNION - THE HYDRA SYNDROME
}

Terrorism can be compared to a dangerous hydra with many different heads (Wojciechowski, 2013a: 11). They symbolize the various types of terrorism, such as Islamic, separatist, far right, far left, and so on (Radicalism, 2017: 49-68). The diversification of the terrorist threat can be easily seen in the European Union as exemplified, for instance, in the latest report by Europol TE-SAT, European Union Terrorism Situation and Trend Report 2017 (TE-SAT, 2017), and the analysis of events in 2016 and 2017.

The main purpose of this text is to answer the following questions, among others: what is the current scale of the terrorist threat in the European Union? What are the characteristics of modern terrorism in the EU? What is its specific nature and how is it evolving? What are its main ideological reasons and types? What is the scope and nature of Islamic terrorism in the European Union? What influence does immigration/ refugeeism have on the level of terrorism? How are we to evaluate the current antiterrorist policy of the EU? What level of terrorist threat seems to be likely in the European Union in the months to come? These issues are discussed in this paper in the ten sections below. The conclusions presented there frequently defy stereotypical opinions and views on terrorism in the EU.

1. According to the data collected by the US Department of State, terrorist attacks in the European Union account for only ca. $2 \%$ of the global manifestations of terrorism (Global, 2015). The index of casualties is even lower. For instance, in 2016, 142 persons were killed and 379 injured in the aftermath of terrorist attacks in the EU. Globally, ca. 28,000 persons were killed and 35,000 injured in 2015. The point here is by no means to belittle the terrorist threat in the EU or its victims, but rather to present the objective scope of the problem. The number of failed, thwarted as well as success-

Figure 1. Number of failed, foiled or completed attacks in EU (2014-2016)

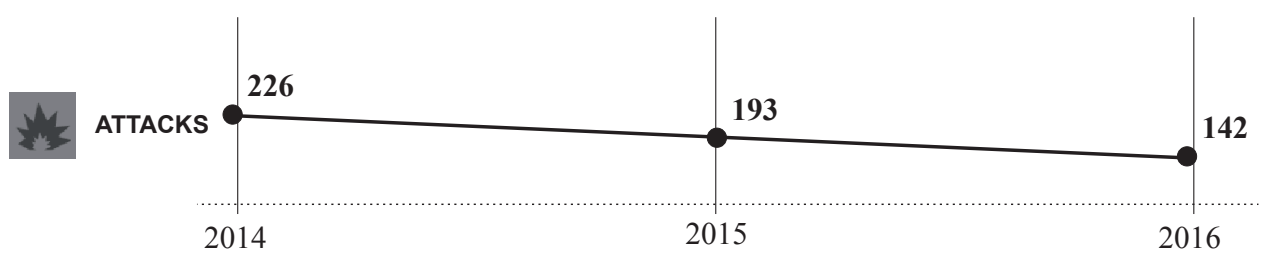

Source: TE-SAT, European Union Terrorism Situation and Trend Report 2017 (2017), https://www.europol.europa.eu/activities-services/main-reports/eu-terrorism-situation-and-trend-report-te-sat-2017 (28.06.2017). 
ful terrorist attacks in the European Union consistently increased in 2013-2015, from 152 in 2013, to 201 in 2014 and 211 in 2015. This trend changed in 2016 when the number of attacks dropped to 142 (TE-SAT, 2014, 2015, 2016, 2017).

The United Kingdom suffered the greatest number of attacks (103) in 2015. It was followed by France (73), Spain (25), Greece (4), Italy (4) and Denmark (2). In 2016, the majority of attacks also occurred in the UK (76), followed by France (23), Italy (17), Spain (10), Greece (6), Germany (5), Belgium (4) and the Netherlands (1). The UK's top ranking in the two latest reports by Europol came as quite a surprise because, formerly, terrorist attacks most frequently occurred in France and Spain (TE-SAT, 2016, 2017).

2. In contrast to popular opinions, jihadist attacks do not prevail in the European Union. For instance, only two out of 199 attacks in 2014 were classified as jihadist. In 2015, seventeen out of the total number of 211 attacks were inspired by Islamic ideology. The data gathered in 2016 shows that the primary reason for 99 out of 142 attacks was separatism, followed by left-wing (27), jihadist (13), non-specified (2) and right-wing (1) ideologies. Terrorism in the EU seems therefore to be heterogeneous and highly diversified ideologically. In 2016, separatist attacks were reported in the UK (76), France (18) and Spain (5). Attacks inspired by far left ideology occurred in Italy (16), Greece (6) and Spain (5). Islamic terrorists attacked in France (5), Belgium (4) and Germany (4). Non-specified attacks were reported in Germany (1) and Italy (1), and there was one far right attack in the Netherlands. In 2016, terrorist attacks occurred, in total, in eight EU member states (TE-SAT, 2017).

Table 1

Overview of the failed, foiled and completed attacks in 2016 per EU member state and per affiliation

\begin{tabular}{||l|c|c|c|c|c|c|r||}
\hline Member State & Jihadist & Left-wing & Right-wing & Separatist & $\begin{array}{c}\text { Single } \\
\text { issue }\end{array}$ & $\begin{array}{c}\text { Not } \\
\text { specified }\end{array}$ & Total \\
\hline Belgium & $\mathbf{4}$ & 0 & 0 & 0 & 0 & 0 & $\mathbf{4}$ \\
\hline France & $\mathbf{5}$ & 0 & 0 & $\mathbf{1 8}$ & 0 & 0 & $\mathbf{2 3}$ \\
\hline Germany & $\mathbf{4}$ & 0 & 0 & 0 & 0 & $\mathbf{1}$ & $\mathbf{5}$ \\
\hline Greece & 0 & $\mathbf{6}$ & 0 & 0 & 0 & 0 & $\mathbf{6}$ \\
\hline Italy & 0 & $\mathbf{1 6}$ & 0 & 0 & 0 & $\mathbf{1}$ & $\mathbf{1 7}$ \\
\hline Netherlands & 0 & 0 & $\mathbf{1}$ & 0 & 0 & 0 & $\mathbf{1}$ \\
\hline Spain & 0 & $\mathbf{5}$ & 0 & $\mathbf{5}$ & 0 & 0 & $\mathbf{1 0}$ \\
\hline UK & 0 & 0 & 0 & $\mathbf{7 6}$ & 0 & 0 & $\mathbf{7 6}$ \\
\hline Total & $\mathbf{1 3}$ & $\mathbf{2 7}$ & $\mathbf{1}$ & $\mathbf{9 9}$ & $\mathbf{0}$ & $\mathbf{2}$ & $\mathbf{1 4 2}$ \\
\hline \hline
\end{tabular}

Source: TE-SAT, European Union Terrorism Situation and Trend Report 2017 (2017), https://www.europol.europa.eu/activities-services/main-reports/eu-terrorism-situation-and-trend-report-te-sat-2017 (20.06.2017).

3. The number of persons detained for terrorist activities inspired by jihadist ideology increased. In 2014, 395 persons were detained, in 2015 - 687, and in 2016 - as many as 718 . The proportion of jihad-inspired terrorists in the total number of detained terrorists also increased considerably, amounting to $70 \%$ in 2016 , compared to $50 \%$ two years before. In 2016, most arrests occurred in France (429), followed by Spain (69), Belgium (62), the Netherlands (36), Austria (30), Italy (28) and Germany (25). 
Poland was the scene of five detentions (the sixth detainee was accused of far right terrorism). Surprisingly, there was not a single detention on Islamist charges in the UK, where one of the largest Muslim communities live, and the group of extreme Islamists there is estimated at ca. 20,000 people. Additionally, as has already been indicated, in 2016, most terrorist attacks occurred in the UK (all of them inspired by separatist ideologies).

Figure 2. Number of suspects arrested for religiously inspired/jihadist terrorism 2012 to 2016

800

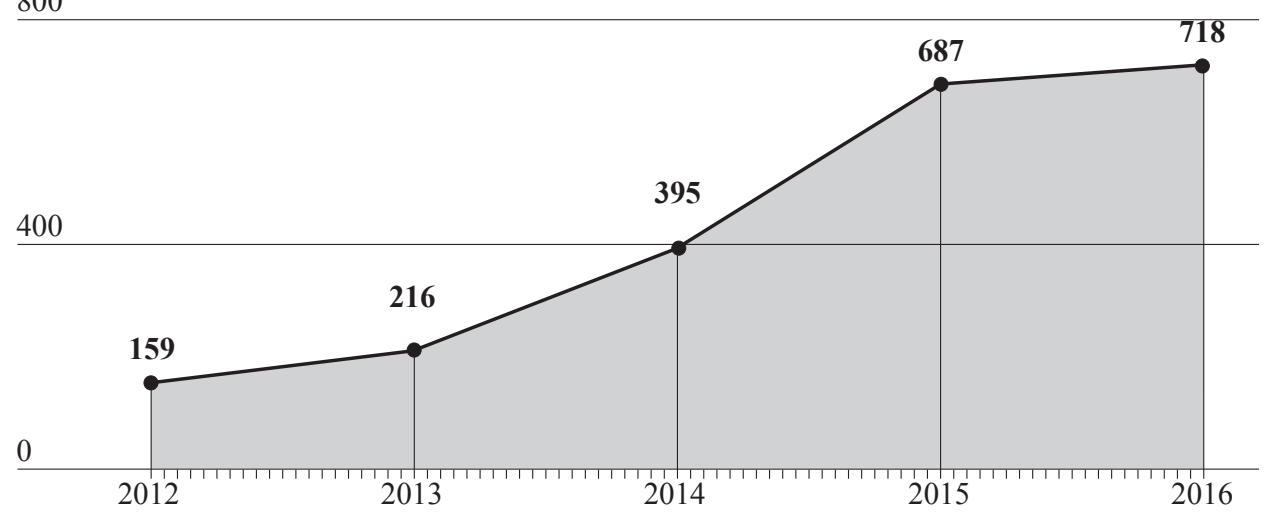

Source: TE-SAT, European Union Terrorism Situation and Trend Report 2017 (2017), https://www.europol.europa.eu/activities-services/main-reports/eu-terrorism-situation-and-trend-report-te-sat-2017 (1.07.2017).

In 2016, 587 persons were convicted for terrorist activities in the European Union. The greatest numbers of such convictions were reported in Spain (157), Belgium (138), the United Kingdom (89), France (68), the Netherlands (42), Germany (30) and Austria (26). The greatest number of sentences were passed on jihadists $(61 \%)$, separatists $(21.3 \%)$, non-specified $(15.7 \%)$, right-wing $(1.5 \%)$ and left-wing $(0.5 \%)$ terrorists (TE-SAT, 2015, 2016, 2017).

Table 2

Number of verdicts in 2016 per EU Member State and per type of terrorism, as reported to Eurojust

\begin{tabular}{||l|c|c|c|c|c|c||}
\hline Member State & Jihadist & Left-wing & Right-wing & Separatist & Not specified & Total \\
\hline \multicolumn{1}{|c|}{1} & 2 & 3 & 4 & 5 & 6 & $\mathbf{7}$ \\
\hline Austria & $\mathbf{2 6}$ & 0 & 0 & 0 & 0 & $\mathbf{2 6}$ \\
\hline Belgium & $\mathbf{1 3 8}$ & 0 & 0 & 0 & 0 & $\mathbf{1 3 8}$ \\
\hline Denmark & $\mathbf{6}$ & $\mathbf{2}$ & 0 & 0 & 0 & $\mathbf{8}$ \\
\hline Estonia & $\mathbf{2}$ & 0 & 0 & 0 & 0 & $\mathbf{2}$ \\
\hline Finland & $\mathbf{4}$ & 0 & 0 & 0 & 0 & $\mathbf{4}$ \\
\hline France & $\mathbf{6 8}$ & 0 & 0 & 0 & 0 & $\mathbf{6 8}$ \\
\hline Germany & $\mathbf{2 8}$ & $\mathbf{2}$ & 0 & 0 & 0 & $\mathbf{3 0}$ \\
\hline Greece & 0 & 0 & $\mathbf{3}$ & 0 & 0 & $\mathbf{3}$ \\
\hline Hungary & 0 & 0 & 0 & $\mathbf{1}$ & $\mathbf{1}$ & $\mathbf{2}$ \\
\hline Italy & $\mathbf{1 1}$ & 0 & 0 & 0 & 0 & $\mathbf{1 1}$ \\
\hline Lithuania & 0 & 0 & 0 & 0 & $\mathbf{1}$ & $\mathbf{1}$ \\
\hline
\end{tabular}




\begin{tabular}{||l|r|r|r|r|r|r||}
\hline \multicolumn{1}{|c|}{1} & 2 & 3 & 4 & 5 & 6 & $\mathbf{7}$ \\
\hline Netherlands & $\mathbf{3 2}$ & $\mathbf{5}$ & 0 & $\mathbf{5}$ & 0 & $\mathbf{4 2}$ \\
\hline Portugal & $\mathbf{1}$ & 0 & 0 & 0 & 0 & $\mathbf{1}$ \\
\hline Slovenia & 0 & 0 & 0 & 0 & $\mathbf{1}$ & $\mathbf{1}$ \\
\hline Spain & $\mathbf{3 8}$ & $\mathbf{1 1 6}$ & 0 & $\mathbf{3}$ & 0 & $\mathbf{1 5 7}$ \\
\hline Sweden & $\mathbf{4}$ & 0 & 0 & 0 & 0 & $\mathbf{4}$ \\
\hline United Kingdom* & 0 & 0 & 0 & 0 & $\mathbf{8 9 * *}$ & $\mathbf{8 9}$ \\
\hline Total & $\mathbf{3 5 8}$ & $\mathbf{1 2 5}$ & $\mathbf{3}$ & $\mathbf{9}$ & $\mathbf{9 2}$ & $\mathbf{5 8 7}$ \\
\hline
\end{tabular}

* The data provided by the United Kingdom was not broken down by type of terrorism and is therefore included under the category 'Not specified'.

** The figures included in the UK submission to the TE-SAT differ from those reported by Eurojust. The UK submission included a figure of 68 , consisting of 56 convictions and 12 acquittals. The TE-SAT is using the Eurojust figures for consistency.

Source: TE-SAT, European Union Terrorism Situation and Trend Report 2017 (2017), https://www.europol.europa.eu/activities-services/main-reports/eu-terrorism-situation-and-trend-report-te-sat-2017 (1.07.2017).

4. When presenting the TE-SAT 2017 report, Europol Director Rob Wainwright stressed that terrorists were increasingly intent on media publicity, and that is why they chose specific locations, targets and forms of attack. This is evidenced by their attacks carried out near sports facilities, concert halls, shopping malls and frequented roads. The profile of perpetrators is also changing. There are more and more women, who accounted for $18 \%$ of all detainees for terrorism in 2015 and $26 \%$ in 2016 . The latest report by Europol brings a disturbing conclusion that terrorists operating in the EU are increasingly determined and professionally prepared, constantly adapting their operational tactics and strategies. A particularly dangerous scenario involves what is called a sequential attack, where a number of attacks are simultaneously carried out in different places and at different distances from one another. This was the case in Paris in 2015 and Jakarta in 2016. Terrorists are not only better trained, but it is increasingly difficult to neutralize them and determine their mutual relations (TE-SAT, 2017).

5. Terrorists will increasingly resort to easily available and simple tools to carry out their attacks, such as knives, axes, speeding cars and so on. At the same time, however, there is a growing threat that Islamists will use weapons of mass destruction, such as chemical, biological and radiological weapons, cyberterrorism and drones. Ben Wallace, UK Minister of State for Security, warned against this very scenario in January 2017, when he referred to a jihadist laboratory the police discovered in Morocco, where chemical and biological weapons could be manufactured. ISIS has an undetermined arsenal of weapons of mass destruction at their disposal which they acquired in Iraq, Syria and Libya, as well as experts in this field. If ISIS continues to suffer further failures, their use of WMD cannot be ruled out (Wojciechowski, Osiewicz, 2017: 192-193).

The particularly underestimated threat is that of the use of biological weapons by Islamic terrorists. Experts especially stress the possibility of using Yersinia pestis in this context. In the early 2017, the World Health Organization officially recognized Yersinia pestis as the greatest biological threat in the modern world. Such an assessment follows from the fact that it is relatively easy to produce, the disease spreads rapidly, the mortality rate is extremely high (for some varieties, e.g. pneumonic 
plague, it is $90-100 \%$ ), there is no appropriate vaccine, the hitherto antibiotics are inefficient, and the bacteria can be easily brought onto the territory of a given state (Giersz, 2017).

6. The authors of the TE-SAT 2017 report claim that it is difficult to identify a direct correlation between the EU's migration policy and the scale of attacks in 2016. The data collected indicates that these attacks were typically conducted by people who had long lived in the EU, they were frequently born there and were citizens of EU member states. It is true that, over the period concerned, new entrants to the EU carried out attacks, but these were isolated cases (TE-SAT, 2017).

Yet the influx of immigrants to the European Union may translate into an increased threat of terrorist attacks. On the one hand, it applies to the activities of Islamic terrorists hiding or seeking support among immigrants and refugees (Wojciechowski, 2016). On the other one, the instances have to be taken into account of terrorism of extremist groups (left-wing, right-wing or separatist) which, for various reasons, oppose or support the influx of immigrants/refugees into the EU. The potential cooperation between terrorists and immigrants and refugees in the EU was confirmed in February 2016 by Hans-Georg Maassen, President of the Federal Office for the Protection of the Constitution, who reported that around one hundred such cases were investigated in Germany (To fakt, 2016). In August 2016, Italian Minister of Foreign Affairs, Andrea Orlando addressed the parliament, talking about serious suspicions concerning the significant role of ISIS in the influx of immigrants/ refugees to Italy by sea. This has been confirmed by the intercepted emails, letters and calls of jihadists which indicate that terrorists may be hiding on the boats carrying people from Libya to Europe.

There are many different threats related to the mass influx of immigrants/ refugees to Europe and their potential ties with terrorist and criminal groups that have to be taken into account. These threats can be divided into criminal and terrorist:

- terrorist threats involve smuggling drugs, weapons, people and so on. Information has been collected indicating that different groups of Islamic terrorists earn profits 'transferring' immigrants/refugees and selling passports. Another matter was the offences committed by some immigrants/refugees in Europe (so-called sex-terror) where women were sexually molested, especially at the time of the New Year and carnival. Such cases were reported mainly in Germany, but there were similar occurrences in Austria and Scandinavia. Apart from their social and political overtones, they have produced serious financial consequences. For instance, additional security measures that were introduced in Cologne during the carnival cost ca. EUR 500,000;

- the terrorist threat can be divided into indirect and direct. The former encompasses, among other things, cases of propaganda, recruitment, intelligence and financial activities. The latter is about causing a direct threat in the form of conventional or unconventional operations. Conventional ones involve bomb attacks and suicide attacks, and the unconventional - using chemical and nuclear materials, constructing 'dirty' bombs, spreading viruses and bacteria, different operations in cyberspace and so on. 
Figure 3. Possible types of threats initiated by terrorists using immigrants/refugees

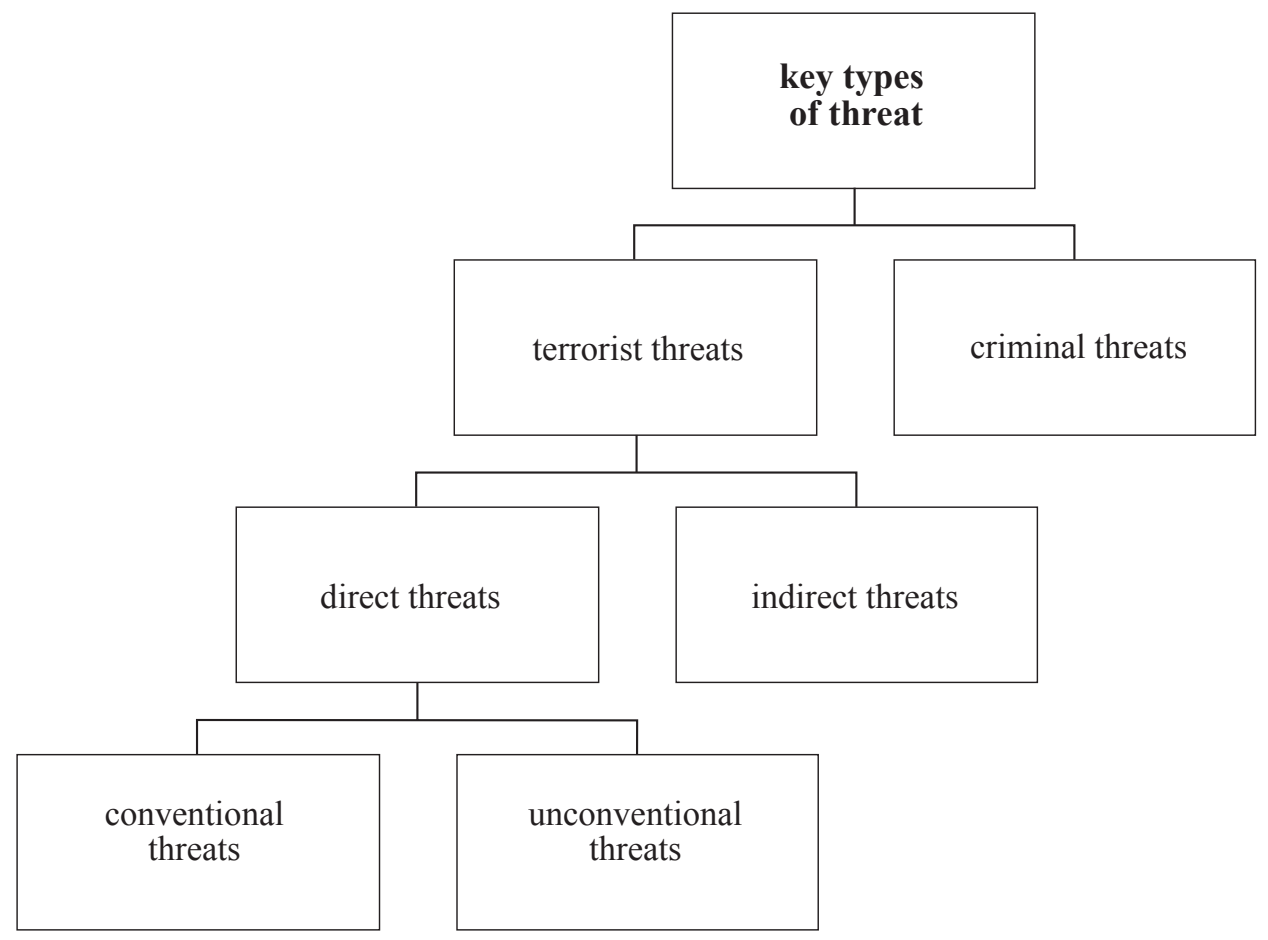

Source: Author's own concept.

The mass influx of immigrants and refugees to the European Union has given rise to a range of political, financial, legislative and logistical challenges. One of them concerns monitoring immigrants/refugees who have entered the territory of the European Union. This is particularly well illustrated by Germany, where in late February 2016, the authorities reported that they did not know the whereabouts of approximately 130,000 immigrants/refugees registered in Germany (which accounted for 13\% of all applications submitted in Germany in 2015). It was stated in the communication that the "possible reasons (for the absence of immigrants/refugees) include their return to their country of origin, traveling on to another country or failing to conform to the regulations [...]. Another explanation involves double entries in the EASY immigration system, which registers applicants for asylum." Regardless of the explanation, over 130,000 individuals are off the grid in Germany alone. This group may include people with criminal or terrorist connections (Niemcy, 2016).

7. The current activities undertaken by the European Union and the majority of member states in terms of combating terrorism have to be deemed insufficient. This primarily concerns inadequate financial resources, an aftermath of the policy of restrictions and reductions launched in the security sector several years ago, which can still be observed (as exemplified by the operations of the police in the United Kingdom) and the lack of comprehensive international cooperation including, for instance, rapid exchange of information in full. The multi-speed policy present in many aspects of 
EU operations is also noticeable in the field of counter-terrorism. This follows from the use of different and frequently incompatible systems of collecting information on terrorists on the one hand, and from differences in the commitment and collaboration of EU member states and their services in combating this threat on the other. Bibi Van Winkel from the International Centre for Counter-Terrorism described it adequately, saying that "not all EU members are ready to share the information they possess to the same extent." It significantly impairs and disorganizes EU anti-terrorist policy and lowers the level of security (Terrorabwehr, 2016).

The TE-SAT 2017 report offers rather vague conclusions on the EU's antiterrorist activities. It points to such shortcomings as the lack of adequate instruments to counter armed drones which could be used by terrorists, among others. Among the significant successes of anti-terrorist policy, the report mentions the curbing of Islamist propaganda on the Internet. Around $90 \%$ of all posts that encourage carrying out attacks, or instruct how to do so were reported to have been immediately removed from the web, while the persons involved in such activities are typically identified and apprehended.

8. One of the latest initiatives aiming to coordinate the activities of member states in the field of counter-terrorism was a new directive on combating terrorism adopted by the European Parliament on February 16, 2017 (the draft was approved by the EU Council in March 2016). It enhances the EU's legislative foundations aimed at preventing terrorist attacks. The regulations stipulated in the directive provide, among other things, for the criminal accountability of travelling abroad with the aim of joining terrorist structures (including individuals who return to the EU with the intention of continuing their terrorist activities); financing, organizing and facilitating such travel; terrorist training and participating in such training sessions; public encouragement of terrorism and glorifying it; as well as financing terrorist activities. The directive also discusses the issue of expanding the exchange of information on anti-terrorist operations between EU member states, and increases the rights of the victims of terrorist activities, urging for them to be provided with specific legal, medical and psychological assistance (European, 2017).

European Union members have eighteen months from the publication of the new regulations in the Official Journal of the European Union to implement them in their national laws. The solutions adopted in the directive were positively assessed by a majority of experts dealing with the issue of terrorism. They have, however, been criticized by Amnesty International and the European Network Against Racism, among others, who claim that these regulations may impair the respect for fundamental rights in the EU, and carry the risk of racial and religious discrimination. In the opinion of these organizations, the regulations "open the door to penalizing behavior that does not have to do with terrorist attacks whatsoever. The broad definitions of the glorification of terrorism or travelling for terrorist purposes may curb human rights."

One of the main goals of the directive is to limit ISIS and its followers' potential to carry out further terrorist attacks in the European Union. This threat remains extremely high, as stressed by Europol in its December 2016 report. Among other things, this report warns about attacks against all EU member states. Europol estimates that there are several dozen jihadists currently staying in the EU who have the power and capacity to 
conduct attacks involving firearms, suicide bombings and other weapons. Kidnappings and the explosions of booby-trapped cars are also possible scenarios (Europol, 2016).

The report stresses that the advocates of ISIS may infiltrate immigrant and refugee communities in Europe in order to instigate their hostility towards the country of their temporary stay, using not only religious and cultural arguments, but also socio-economic and legislative ones. It is emphasized that Islamists are more and more specialized in recruiting marginalized young people and people with mental disorders, urging them to carry out suicide attacks. Additionally, fundamentalists are eager to recruit children and electronic media experts. This is confirmed by the FBI, which has learned that Islamic terrorists lack experts on social media and Internet propaganda due to the range of operations of US special services (including, for instance, neutralization by drones).

Another topic addressed in the directive is the recommendation to strictly monitor immigrant and refugee camps, and destroy terrorist training camps. This pertains not only to the Middle East and the Balkan Peninsula, but also to EU states. This is exemplified by Greece, where a fifty-strong team of Europol experts is operating in order to expose terrorists hiding in immigrant and refugee camps. Yet experts on terrorism differ in their assessments of this method. Some of them believe that it will hamper extremist activities and reduce the level of radical attitudes. Others stress the low efficiency of such activities on account of the huge numbers of people in the camps and frequently effective camouflage of terrorists. Another significant issue concerns a range of mistakes and faults in the security sector. This is well exemplified by the case of Brussels officials who took bribes of approximately EUR 20,000 and forged the passports of several ISIS fighters returning from abroad and fearing arrest. Europol itself was not free of problems. As a result of a breach of regulations by one of Europol's officials, the details of around fifty anti-terrorist investigations, including the names and phone numbers of suspects, were posted on the Internet.

9. An important condition to combat terrorism in the EU involves tight cooperation with the US, NATO, Israel and Turkey, to name just a few. Europol's director has emphasized it on numerous occasions, stressing that the threat related to terrorism in the EU can be resolved only by further improving international collaboration. The meeting held by NATO member states' leaders on May 25, 2017 is one of the most recent examples of such collaboration. Several crucial decisions were made during this meeting, including the permission for NATO to join a coalition combating ISIS and establishing a special unit dedicated to counter-terrorism. The coalition of states struggling against ISIS included 68 states, applying a range of measures to prevent the Islamist threat. Some take part in air rides against jihadist positions, others support the forces fighting ISIS in Syria and Iraq, participate in special operations or offer humanitarian aid. The official announcement of this decision was made by NATO Secretary General Jens Stoltenberg, who stressed that whereas NATO had joined the international coalition, this was not to mean that the Pact was automatically involved in the struggle with ISIS (Wejkszner, 2017; Atwan, 2015). The primary goals of NATO will be to continue the training of Iraqi forces in disarming improvised explosive devices, enhance intelligence collaboration and extend information exchange, continue the support for electronic reconnaissance and carry out operations refueling coalition airplanes. 
10. Further escalation of terrorism, especially Islamic terrorism, should be expected in the European Union in the second half of 2017. This threat will no longer be limited just to France, Germany, Belgium, the Netherlands and the United Kingdom, but will concern other member states which have not witnessed such attacks before. There are many reasons for that, including the fact that, having suffered a series of defeats in Syria and Iraq, ISIS needs spectacular successes to mobilize its followers to continue struggling. This is also a manifestation of the strategy of 'creating new front lines,' or carrying out attacks in new locations and making use of the determination and radicalism of some of its supporters. Director of Europol, Rob Wainwright has repeatedly stressed this, noting that ISIS decided to send 'fanatics' to Europe in order to distract attention from its failures in Syria and Iraq; he also added that "the ability to carry out spectacular attacks in Europe is an alternative way to sustain morale among their fighters and demonstrate that ISIS is still being successful." The greatest threat of Islamic terrorism is posed not by persons who fought with ISIS troops and then returned to the European Union for various reasons and in different ways. These people can usually be monitored. The same holds true for the Islamists who live in the EU and conduct radical activities on Internet fora and in mosques. The most dangerous people are those who identify themselves with Islamic fundamentalism and are prone to using terrorism, but who do not reveal their views in public.

The above-presented observations demonstrate the complex and diverse nature of terrorism in the European Union (the many-headed hydra syndrome). They also reflect the on-going evolution of terrorism and a number of aspects that defy media opinions and stereotypes.

\section{BIBLIOGRAPHY}

Atwan A. (2015), Islamic State. The Digital Caliphate, Oakland.

Giersz A. (2017), Czarna Śmierć może wrócić. Terroryści chcq wykorzystać bakterie dżumy, "Polska Times", 5.02.2017, http://www.polskatimes.pl/magazyny/magazyn-polski/a/czarna-smiercmoze-wrocic-terrorysci-chca-wykorzystac-bakterie-dzumy,11761026/ (4.07.2017).

Europol ostrzega: Dżihadyści moga planować kolejne ataki terrorystyczne w Europie (2016), Wprost.pl, 2.12.2016, https://www.wprost.pl/swiat/10033216/Europol-ostrzega-Dzihadyscimoga-planowac-kolejne-ataki-terrorystyczne-w-Europie.html (2.02.2017).

Global Terrorism Index 2015. Measuring and Understanding the Impact of Terrorism (2015), Institute for Economics \& Peace, http://economicsandpeace.org/wp-content/uploads/2015/11/ Global-Terrorism-Index-2015.pdf (17.06.2017).

European Parliament legislative of 16 February 2017 on the proposal for a directive of the European Parliament and of the Council on combating terrorism (2017), www.europarl.europa. eu (6.05.2017).

European Union Terrorism Situation and Trend Report 2014 (2014), http://www.europol.europa.eu (19.06.2017).

European Union Terrorism Situation and Trend Report 2015 (2015), https://www.europol.europa.eu/ activities-services/main-reports/european-union-terrorism-situation-and-trend-report-2015 (15.06.2017). 
European Union Terrorism Situation and Trend Report 2016 (2016), https://www.europol.europa. eu/activities-services/main-reports/european-union-terrorism-situation-and-trend-report-tesat-2016 (19.06.2017).

European Union Terrorism Situation and Trend Report 2017 (2017), https://www.europol.europa. eu/activities-services/main-reports/eu-terrorism-situation-and-trend-report-te-sat-2017 (2.07.2017).

Niemcy: władze nie wiedza co dzieje się ze 130 tys. uchodźców (2016), Wirtualna Polska, 26.02.2016, https://wiadomosci.wp.pl/niemcy-wladze-nie-wiedza-co-dzieje-sie-ze-130-tys-uchodzcow6027654662816897a (28.10.2016).

Radicalism and Terrorism in the $21^{\text {st }}$ Century. Implications for Security (2017), (eds.) F. Castro-Rial Garrone, R. Dario Torres Kumbrián, A. Sroka, Frankfurt am Main.

Terrorabwehr: Kooperation mit Hindernissen, http://www.dw.com (21.12.2016).

To fakt: Ekstremiści ISIS udajq uchodźców (2017), “Głos Wielkopolski”, 6-7.02.2017.

Wejkszner A. (2017), Państwo Islamskie. Narodziny nowego kalifatu?, Warszawa.

Wejkszner A. (2017), Globalna sieć Al-Kaidy. Nowe Państwo Islamskie?, Warszawa.

Wojciechowski S. (2017), Reasons of Contemporary Terrorism. An Analysis of Main Determinants, w: Radicalism and Terrorism in the $21^{\text {st }}$ Century. Implications for Security, (eds.) F. CastroRial Garrone, R. Dario Torres Kumbrián, A. Sroka, Frankfurt am Main.

Wojciechowski S. (2013a), Terroryzm na poczatku XXI wieku. Pojęcie - Przejawy - Przyczyny, Warszawa.

Wojciechowski S. (2013b), The Hybridity of Terrorism. Understanding Contemporary Terrorism, Berlin.

Wojciechowski S., Osiewicz P. (2017), Zrozumieć wspótczesny terroryzm. Wybrane aspekty fenomеnu, Warszawa.

Wojciechowski S., Siadkowski A. (2014), Understanding Contemporary Terrorism and Counterterrorism, Dąbrowa Górnicza.

Wojciechowski S. (2016), Uchodźcy a zagrożenie terrorystyczne na przykładzie Unii Europejskiej, w: Uchodźcy w Europie, Uwarunkowania - Istota - Następstwa, (red.) K. Wojtaszczyk, J. Szymańska, Warszawa.

\begin{abstract}
Terrorism can be compared to a dangerous hydra with many different heads. They symbolize the various types of terrorism, such as Islamic, separatist, far right, far left, and so on. The diversification of the terrorist threat can be easily seen in the European Union as exemplified, for instance, in the latest report by Europol TE-SAT, European Union Terrorism Situation and Trend Report 2017, and the analysis of events in 2016 and 2017. The main purpose of this text is to answer the following questions, among others: what is the current scale of the terrorist threat in the European Union? What are the characteristics of modern terrorism in the EU? What is its specific nature and how is it evolving? What are its main ideological reasons and types? What is the scope and nature of Islamic terrorism in the European Union? What influence does immigration/refugeeism have on the level of terrorism? How are we to evaluate the current anti-terrorist policy of the EU? What level of terrorist threat seems to be likely in the European Union in the months to come? These issues are discussed in this paper in the ten sections below. The conclusions presented there frequently defy stereotypical opinions and views on terrorism in the EU.
\end{abstract}

Keywords: terrorism, terrorism in the EU, ISIS, Europol 


\title{
WSPÓLCZESNY TERRORYZM W UNII EUROPEJSKIEJ - SYNDROM ,WIELOGLOWEJ" HYDRY
}

\begin{abstract}
STRESZCZENIE
Terroryzm można przyrównać do niebezpiecznej „hydry” o wielu różnorodnych głowach. Są one symbolem różnych jego form, takich jak na przykład terroryzm: islamistyczny, separatystyczny, skrajnie prawicowy (right-wing), skrajnie lewicowy (left-wing) itd. Zróżnicowanie terrorystycznego zagrożenia dobrze można obserwować na przykładzie Unii Europejskiej. Ukazuje to choćby najnowszy raport Europolu pt. TE-SAT, European Union Terrorism Situation and Trend Report 2017, a także analiza wydarzeń z 2016 i 2017 roku. Głównym celem tekstu jest odpowiedź między innymi na następujące pytania: Jaka jest obecnie skala terrorystycznego zagrożenia w Unii Europejskiej? Co charakteryzuje współczesny terroryzm w UE? Na czym polega jego specyfika i ewolucja? Jakie są jego główne ideologiczne przyczyny oraz rodzaje? Jaki jest zakres i charakter terroryzmu islamistycznego w Unii Europejskiej? Jak zjawisko imigracji/uchodźstwa wpływa na poziom terroryzmu? Jak należy ocenić obecną politykę antyterrorystyczną UE? Jak w kolejnych miesiącach może wyglądać poziom zagrożenia terrorystycznego w Unii Europejskiej? Powyższe zagadnienia zostały zaprezentowane w tekście w oparciu o formułę dziesięciu punktów. Zawarte w nich wnioski często obalają stereotypowe opinie czy wyobrażenia na temat terroryzmu w UE.
\end{abstract}

Słowa kluczowe: terroryzm, terroryzm w Unii Europejskiej, Państwo Islamskie, Europol 
